\title{
The Antibiotic Prescription Practice in Primary Health Care from the Pharmacist Perspective
}

\author{
Bojana Z. Čović', ${ }^{1,}$ Nemanja B. Todorović ${ }^{2}$ Jelena M. Čanji ${ }^{2}$, \\ Katarina D. Jeremić2 , Jelena N. Jovičić-Bata², Đurđa M. Cvjetkovićs, \\ Mladena N. Lalić-Popovićn ${ }^{2,4}$ \\ ${ }^{1}$ Alkaloid AD Skopje, Belgrade, Serbia \\ ${ }^{2}$ Department of Pharmacy, Faculty of Medicine Novi Sad, University of Novi Sad, Novi Sad, \\ Serbia \\ ${ }^{3}$ Department of Pharmacology, Toxicology and Clinical Pharmacology, Faculty of Medicine \\ Novi Sad, University of Novi Sad, Novi Sad, Serbia \\ ${ }^{4}$ University of Novi Sad, Faculty of medicine Novi Sad, Center for Medical and Pharmaceutical \\ Investigations and Quality Control (CEMPhIC), Novi Sad, Serbia
}

\section{SUMMARY}

Introduction: Antibiotic resistance is a growing problem. Adherence to national guidelines is one of the key factors necessary for the rational use of antibiotics.

Aim: The aim of the study was to examine characteristics of antibiotic prescribing practice in primary health care in Novi Sad.

Method: The analysis was designed as a descriptive, cross-sectional study based on the data obtained from the health institution Cvejić Pharmacy. The guidelines available to physicians at the time of prescribing were used to assess the compliance of the prescribed antibiotics with the guidelines. Additionally, the most frequently dispensed antibiotics for all diagnoses were recorded and results were expressed as a percentage of frequency of analyzed antibiotic prescriptions.

Results: The study has shown that antibiotic prescriptions make $5.48 \%$ of all prescriptions (719 out of 13115), $513(71.35 \%)$ of which were established by national guidelines, and $206(28.65 \%)$ for less frequent diagnoses which was not included in national guidelines. In the study sample, $297(65.42 \%)$ terapeutical regimes had adequate terapeutical dosage. The most commonly prescribed antibiotic groups were: macrolides (35.18\%), penicillins $(28.68 \%)$ and cephalosporins $(14.60 \%)$.

Conclusions: Irrational prescribing and dispensing of antibiotics is both national and global problem. It is necessary to pay close attention to antibiotics prescribing and dispensing. The focus should be on national guidelines and their extension.

Keywords: prescribing practice, guidelines, prescribing and dispensing antibiotics, bacterial resistance 


\section{INTRODUCTION}

Antibiotic resistance, caused by widespread and non-specific use of antibiotics, led to a global public health problem [1,2]. The World Health Organization has proclaimed important messages regarding the control and reduction of bacterial resistance. Adherence to local guidelines during prescribing and dispensing antibiotics is the most important one [3]. Almost half of the prescribed antibiotics have inadequate use. This leads to a decrease in their effectiveness [4,5]. Global antibiotic consumption has increased dramatically, 2.5 times over a 1.5-decade time span (2000-2015) [6]. This is a multilevel problem: this group of medicines is being prescribed for diagnoses for which no antibiotic use has been indicated at all, another problem is making the wrong choice of antibiotics for the treatment of bacterial infections, also there is the issue of adherence in making appropriate drug choices [7]. One important factor in reducing resistance is decreasing prescribing and dispensing of inappropriate antibiotic prescriptions [8]. Globally, 700000 people die from infections caused by resistant strains of bacteria. Unless rational action is taken on a global scale, it is predicted that millions of deaths a year caused by drug-resistance infections would happen by 2050 [9]. Nowadays, the European Medicines Agency is making efforts to find the best solution for the current problem. Furthermore, with the recent spread of bacterial resistance, there is no corresponding progress in the development of new antibiotic molecules. For those reasons, the attention will be carefully focused on boosting research, on development of new therapeutic entities on one hand, and providing guidelines for downsizing the use of existing antibiotics on the other hand. It is estimated that the European Union has been losing 1.5 billion euros annually at the expense of age-related bacterial resistance [10]. Considering that the vast majority of antibiotics are prescribed in primary care [11], we have decided to examine what prescribing practice is present in our country. National guidelines are contained in Pharmacotherapy Protocols in Primary Health Care - the most common diseases and conditions from 2014. Protocol selection is made according to therapy for the most common diagnosis (MCD) established by The National Health Insurance Fund (NHIF) [12].
AIM

The aim of the study was to examine characteristics of antibiotic prescribing practice in primary health care in Novi Sad.

\section{METHOD}

The analysis was designed as a non-commercial, descriptive, cross-sectional study based on the data obtained from the health institution Cvejić pharmacy. Seven branches of the pharmacy in Novi Sad (the second-largest city by population in Serbia) were observed during January 2018. Data taken for analysis is related to dispensed antibiotics, which were prescribed according to prescription patterns funded by NHIF. Data was chosen randomly. Prescription patterns of dispensed antibiotics that are not recognized by NHIF for funding were not considered, due to the incompleteness of the data of the observed parameters.

Data regarding gender, age, diagnosis and prescribed/dispensed medicines were recorded. For each observed diagnosis, the frequency of each therapeutic choice was recorded. The same therapeutic choice was considered to be medicines with the same active pharmaceutical ingredient (API) in the same total therapeutic dose (TTD), from different producers. Prescriptions for antibiotics with dosage based on body weight were excluded from the study (excluded prescriptions) due to the lack of required data when classifying the prescribed medicine into one of four groups: appropriate medicine, appropriate but subdosed medicine, appropriate but supradosed medicines and inappropriate medicine.

This paper assess the compliance of the prescribed antibiotics with the available guidelines. Pharmacotherapy Protocols in Primary Health Care for the most common diseases and conditions from 2014, issued by NHIF, were used, written by national experts in the specific areas for which the guideline is intended [12]. The guidelines prescribe therapies for the most common diagnoses in primary health care (MCD). Only these diagnoses were observed to evaluate the compliance of the prescribed therapies with the guidelines in this study. The necessary minimum and maximum TTD for the individual diagnosis and each age category of patients were calculated based on the guidelines The dispensed doses were compared with the calculated ones 
Figure 1. Selection of prescriptions for analysis

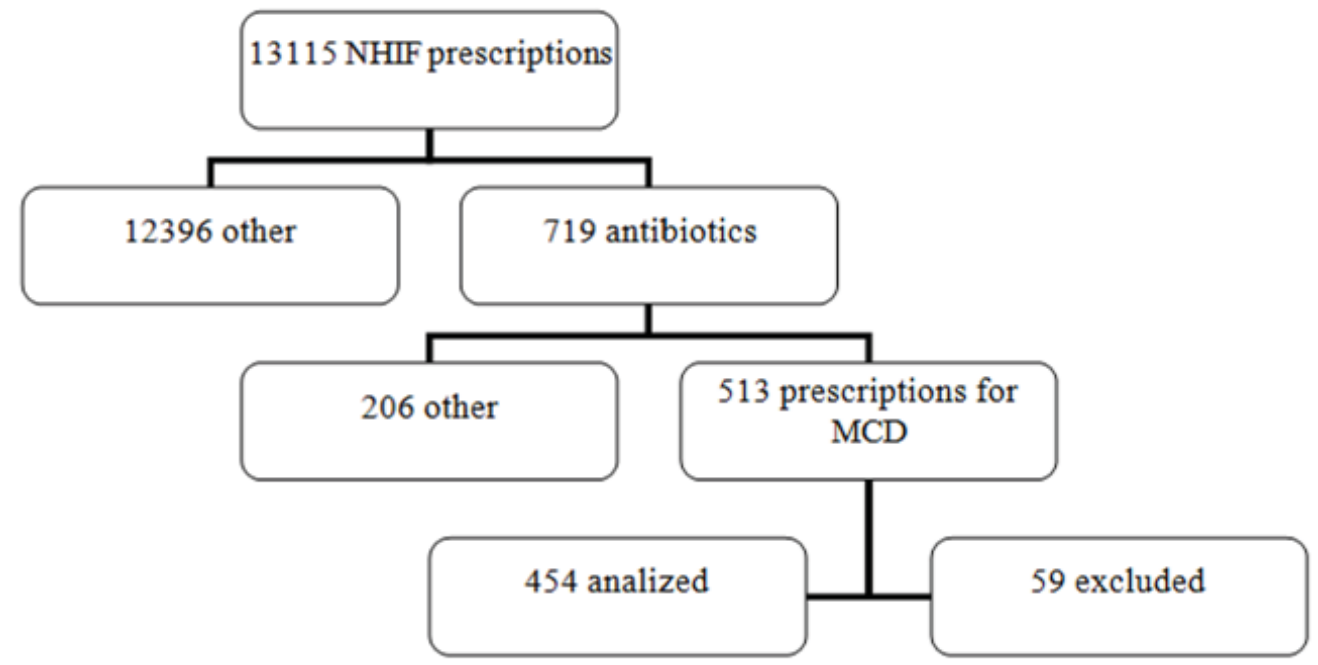

to asses suitability. Additionally, the most frewere recorded. The prescriptions selected for analysis are given in Figure 1. quently dispensed antibiotics for all diagnoses
Table 1. Features of prescriptions prescribed for MCD

* Prescriptions for most common diagnosis:

J02 - Acute pharyngitis;

J20 - Acute bronchitis;

J00 - Acute nasopharyngitis;

J03 - Acute tonsillitis;

J01 - Acute sinusitis;

J02.9 - Acute nonspecific pharyngitis;

N30 - Cystitis;

J04 - Acute laryngitis and tracheitis;

H65 - Middle ear inflammation;

L02 - Abscess, ulcer and group of ulcers;

L08 - Other localized infections of the skin and subcutaneous infections.

** Other diagnosis:

H60 - External ear inflammation;

H66 - Purulent and nonspecific middle ear inflammation;

I10 - Hypertension of unknown origin;

J40 - Nonspecific acute or chronic bronchitis;

J42 - Chronic nonspecific bronchitis;

K21 - Gastro-esophageal reflux disease;

K30 - Dyspepsia;

N34 - Urethritis and vaginal inflammation;

N40 - Prostatic hyperplasia;

N76 - Vulvovaginitis;

N72 - Cervicitis.

\begin{tabular}{|c|c|c|c|c|c|c|c|}
\hline & & & Prescript & ons for $\mathrm{m}$ & st commor & diagnosis* & \\
\hline & TOTAL & $\mathrm{J} 02$ & $\mathrm{~J} 20$ & $\mathrm{~J} 00$ & $\mathrm{JO3}$ & $\mathrm{J} 01$ & $\mathrm{~J} 02.9$ \\
\hline GENDER & & & & & & & \\
\hline Male & $170(33.14 \%)$ & 77 (38\%) & $21(30 \%)$ & $17(25 \%)$ & $8(19 \%)$ & $8(24 \%)$ & $10(31 \%)$ \\
\hline Female & $250(48.73 \%)$ & $100(50 \%)$ & $30(43 \%)$ & $26(39 \%)$ & $20(48 \%)$ & 25 (74\%) & $18(56 \%)$ \\
\hline Children & $93(18.13 \%)$ & $24(12 \%)$ & $19(27 \%)$ & $24(36 \%)$ & $14(33 \%)$ & $1(2 \%)$ & $4(13 \%)$ \\
\hline AGE & & & & & & & \\
\hline $0-17$ & $104(20.27 \%)$ & $30(15 \%)$ & $19(27 \%)$ & $24(36 \%)$ & $14(33 \%)$ & $5(15 \%)$ & $4(13 \%)$ \\
\hline $18-35$ & $81(15.79 \%)$ & $39(19 \%)$ & $5(7 \%)$ & $6(9 \%)$ & $16(38 \%)$ & $5(15 \%)$ & $5(16 \%)$ \\
\hline $36-64$ & $224(43.67 \%)$ & 93 (46\%) & $27(39 \%)$ & $28(42 \%)$ & $12(29 \%)$ & $21(62 \%)$ & $17(53 \%)$ \\
\hline$>65$ & $104(20.27 \%)$ & 39 (19\%) & $19(27 \%)$ & $9(13 \%)$ & $0(0 \%)$ & $3(9 \%)$ & $6(19 \%)$ \\
\hline TTD & & & & & & & \\
\hline Analyzed & $454(88.50 \%)$ & $190(95 \%)$ & $51(73 \%)$ & $52(78 \%)$ & $35(83 \%)$ & $34(100 \%)$ & $29(90.5 \%)$ \\
\hline Excluded & 59 (11.50\%) & $11(5 \%)$ & $19(27 \%)$ & $15(22 \%)$ & $7(17 \%)$ & $0(0 \%)$ & $3(9.5 \%)$ \\
\hline & & Pres & criptions fc & most con & mon diagn & sis* & \\
\hline & TOTAL & N30 & $\mathrm{J} 04$ & H65 & L02 & L08 & Others** \\
\hline GENDER & & & & & & & \\
\hline Male & $170(33.14 \%)$ & $9(41 \%)$ & $2(25 \%)$ & $4(57 \%)$ & $4(80 \%)$ & $1(20 \%)$ & $9(45 \%)$ \\
\hline Female & $250(48.73 \%)$ & 13 (59\%) & $5(62 \%)$ & $0(0 \%)$ & $1(20 \%)$ & $3(60 \%)$ & $9(45 \%)$ \\
\hline Children & $93(18.13 \%)$ & $0(0 \%)$ & $1(13 \%)$ & $3(43 \%)$ & $0(0 \%)$ & $1(20 \%)$ & $2(10 \%)$ \\
\hline AGE & & & & & & & \\
\hline $0-17$ & $104(20.27 \%)$ & $0(0 \%)$ & $1(13 \%)$ & $4(57 \%)$ & $0(0 \%)$ & $1(20 \%)$ & 2 (10\%) \\
\hline $18-35$ & $81(15.79 \%)$ & $2(9 \%)$ & $0(0 \%)$ & $1(14 \%)$ & $0(0 \%)$ & $0(0 \%)$ & $2(10 \%)$ \\
\hline $36-64$ & $224(43.67 \%)$ & $7(32 \%)$ & $4(50 \%)$ & $0(0 \%)$ & $4(80 \%)$ & $3(60 \%)$ & $8(40 \%)$ \\
\hline$>65$ & $104(20.27 \%)$ & 13 (59\%) & $3(37 \%)$ & $2(29 \%)$ & $1(20 \%)$ & $1(20 \%)$ & $8(40 \%)$ \\
\hline TTD & & & & & & & \\
\hline Analyzed & $454(88.50 \%)$ & $22(100 \%)$ & $7(87 \%)$ & $6(86 \%)$ & $5(100 \%)$ & $5(100 \%)$ & $18(90 \%)$ \\
\hline Excluded & 59 (11.50\%) & $0(0 \%)$ & 1 (13\%) & $1(14 \%)$ & $0(0 \%)$ & $0(0 \%)$ & $2(10 \%)$ \\
\hline
\end{tabular}




\section{RESULTS}

The study has shown that antibiotic prescriptions make $5.48 \%$ of all prescriptions ( 719 out of 13115), 513 (71.35\%) of which were established by national guidelines, and $206(28.65 \%)$ for less frequent diagnoses which were not included into the national guidelines. The incidence of diagnoses in the examined sample was: J02 (39.18\%), J20 (13.65\%), J00 (13.06), J03 (8.19\%), J01 (6.63\%), J02.9 (6.24\%), N30 (4.29), J04 (1.56\%), H65 (1.36\%), L02 (0.98\%), L08 (0.97) and others (3.89\%). Most of the observed diagnoses were more frequent in female $(49.5 \%)$ compared to male $(32.5 \%)$, while the incidence in children $(<18$ years) was the lowest $(18 \%)$. The exceptions are diagnoses J00 (36\%) and J03 (33\%). The inappropriateness of antibiotic prescription was assessed via rate of sub- and supra- doses, as well as unsuitable indications. An example of an unsuitable indication was antibiotic prescription not recommended by national guidelines. The results of the most commonly prescribed diagnoses established by national guidelines are shown in Table 1 and Table 2. The results of the most commonly used antibiotic groups, as well as the most commonly used antibiotics, are shown in Chart 1 and Chart 2 respectively.

\begin{tabular}{|c|c|c|c|c|c|c|c|}
\hline \multirow{3}{*}{ TTD } & \multirow{3}{*}{ TOTAL } & \multicolumn{6}{|c|}{ Prescriptions for most common diagnosis* } \\
\hline & & \multirow{2}{*}{ J02 } & \multirow[t]{2}{*}{$\mathrm{J} 20$} & \multirow[t]{2}{*}{$\mathrm{J} 00$} & \multirow[t]{2}{*}{$\mathrm{J} 03$} & \multirow{2}{*}{ J01 } & \multirow{2}{*}{$\mathrm{J} 02.9$} \\
\hline & & & & & & & \\
\hline Appropriate & $\begin{array}{c}297 \\
(65.42 \%)\end{array}$ & $\begin{array}{c}140 \\
(73.68 \%)\end{array}$ & $\begin{array}{c}19 \\
(37.25 \%)\end{array}$ & $\begin{array}{c}43 \\
(82.69 \%)\end{array}$ & $\begin{array}{c}23 \\
(65.71 \%)\end{array}$ & $\begin{array}{c}19 \\
(56 \%)\end{array}$ & $\begin{array}{c}28 \\
(96.55 \%)\end{array}$ \\
\hline Inappropriate & $\begin{array}{c}95 \\
(20.93 \%)\end{array}$ & $\begin{array}{c}27 \\
(14.21 \%)\end{array}$ & $\begin{array}{c}32 \\
(62.75 \%)\end{array}$ & $\begin{array}{c}8 \\
(15.38 \%)\end{array}$ & $\begin{array}{c}2 \\
(5.71 \%)\end{array}$ & $\begin{array}{c}11 \\
(32 \%)\end{array}$ & $\begin{array}{c}0 \\
(0 \%)\end{array}$ \\
\hline Subdose & $\begin{array}{c}32 \\
(7.05 \%)\end{array}$ & $\begin{array}{c}16 \\
(8.42 \%)\end{array}$ & $\begin{array}{c}0 \\
(0 \%)\end{array}$ & $\begin{array}{c}1 \\
(1.93 \%)\end{array}$ & $\begin{array}{c}8 \\
(22.86 \%)\end{array}$ & $\begin{array}{c}3 \\
(9 \%)\end{array}$ & $\begin{array}{c}0 \\
(0 \%)\end{array}$ \\
\hline \multirow[t]{3}{*}{ Supradose } & $\begin{array}{c}30 \\
(6.60 \%)\end{array}$ & $\begin{array}{c}7 \\
(3.69 \%)\end{array}$ & $\begin{array}{c}0 \\
(0 \%)\end{array}$ & $\begin{array}{c}0 \\
(0 \%)\end{array}$ & $\begin{array}{c}2 \\
(5.72 \%)\end{array}$ & $\begin{array}{c}1 \\
(3 \%)\end{array}$ & $\begin{array}{c}1 \\
(3.45 \%)\end{array}$ \\
\hline & & \multicolumn{5}{|c|}{ Prescriptions for most common diagnosis* } & \\
\hline & TOTAL & N30 & $\mathrm{J} 04$ & H65 & L02 & L08 & Others** \\
\hline \multicolumn{8}{|l|}{ TTD } \\
\hline Appropriate & $\begin{array}{c}297 \\
(65.42 \%)\end{array}$ & $\begin{array}{c}0 \\
(0 \%)\end{array}$ & $\begin{array}{c}7 \\
(100 \%)\end{array}$ & $\begin{array}{c}4 \\
(66.67 \%)\end{array}$ & $\begin{array}{c}4 \\
(80 \%)\end{array}$ & $\begin{array}{c}0 \\
(0 \%)\end{array}$ & $\begin{array}{c}10 \\
(55.55 \%)\end{array}$ \\
\hline Inappropriate & $\begin{array}{c}95 \\
(20.93 \%)\end{array}$ & $\begin{array}{c}3 \\
(14 \%)\end{array}$ & $\begin{array}{c}0 \\
(0 \%)\end{array}$ & $\begin{array}{c}0 \\
(0 \%)\end{array}$ & $\begin{array}{c}1 \\
(20 \%)\end{array}$ & $\begin{array}{c}4 \\
(80 \%)\end{array}$ & $\begin{array}{c}7 \\
(38.88 \%)\end{array}$ \\
\hline Subdose & $\begin{array}{c}32 \\
(7.05 \%)\end{array}$ & $\begin{array}{c}0 \\
(0 \%)\end{array}$ & $\begin{array}{c}0 \\
(0 \%)\end{array}$ & $\begin{array}{c}2 \\
(33.33 \%)\end{array}$ & $\begin{array}{c}0 \\
(0 \%)\end{array}$ & $\begin{array}{c}1 \\
(20 \%)\end{array}$ & $\begin{array}{c}1 \\
(5.57 \%)\end{array}$ \\
\hline Supradose & $\begin{array}{c}30 \\
(6.60 \%)\end{array}$ & $\begin{array}{c}19 \\
(86 \%)\end{array}$ & $\begin{array}{c}0 \\
(0 \%)\end{array}$ & $\begin{array}{c}0 \\
(0 \%)\end{array}$ & $\begin{array}{c}0 \\
(0 \%)\end{array}$ & $\begin{array}{c}0 \\
(0 \%)\end{array}$ & $\begin{array}{c}0 \\
(0 \%)\end{array}$ \\
\hline
\end{tabular}

\section{DISCUSSION}

The vast majority of patients received the appropriate medication, but some did not receive the appropriate dose. In addition to the API, the guidelines prescribe the dose and duration of therapy for specific diagnoses. Based on this, we observed the minimum and maximum dose required for the overall treatment of infection given in the guidelines and the compliance of the dispensed medicines with the guidelines [12].

Due to the lack of data to evaluate the TTD (dosing is calculated in relation to body weight), 59 (11.5\% of 513$)$ patients were ex-
Table 2. Frequency of analyzed antibiotic prescriptions for the most commonly prescribed diagnoses and their classification according to recommended TTD

* Prescriptions for most common diagnosis:

J02 - Acute pharyngitis;

J20 - Acute bronchitis;

J00 - Acute nasopharyngitis;

J03 - Acute tonsillitis;

J01 - Acute sinusitis;

J02.9 - Acute nonspecific pharyngitis;

N30 - Cystitis;

J04 - Acute laryngitis and tracheitis;

H65 - Middle ear inflammation; L02 - Abscess, ulcer and group of ulcers;

L08 - Other localized infections of the skin and subcutaneous infections.

** Other diagnosis:

H60 - External ear inflammation;

H66 - Purulent and nonspecific middle ear inflammation;

I10 - Hypertension of unknown origin;

J40 - Nonspecific acute or chronic bronchitis;

J42 - Chronic nonspecific bronchitis; of TTD was in line with the observed guideline - 297 (65.42\%). It was found that 62 (13.65 $\%)$ patients had a wrongly prescribed dose (adequate medicine, but underdosed $7.05 \%$, adequate medicine but overdosed $6.60 \%$ ) and $95(20.93 \%)$ received an antibiotic not given in the guidelines. Adherence to national primary health care guidelines was discussed in studies conducted in England, Germany, Cape Town, South Africa, as well as in the WHO pilot study [13 - 17]. Two studies conducted
K21 - Gastro-esophageal reflux disease;

K30 - Dyspepsia;

N34 - Urethritis and vaginal inflammation;

N40 - Prostatic hyperplasia;

N76 - Vulvovaginitis;

N72 - Cervicitis. 
Chart 1. Most commonly used groups of antibiotics
Chart 2. Most commonly used antibiotics

\section{Antibiotic grups}

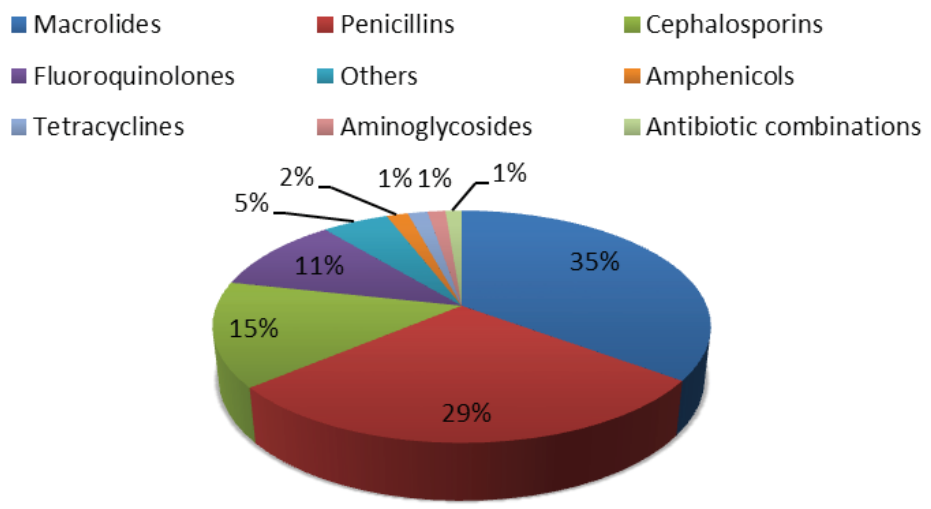

in England have recorded low adherence rates to national guides $[13,14]$. A study conducted in Germany found that most antibiotic prescriptions $(74.82 \%)$ were not in line with the guidelines, $95.66 \%$ of which were related to the diagnosis of acute bronchitis [15]. The smallest deviation from the guidelines, among the comparative trials of recent date, was found in the survey conducted in Cape Town, South Africa, where a non-compliance with the guidelines was $54.6 \%$ of observed cases [16]. International guidelines promote raising awareness of the rational use of antibiotics, especially in case of therapy for acute respiratory infections, where routine antibiotic therapy is not recommended or it is rarely required $[20,21]$.

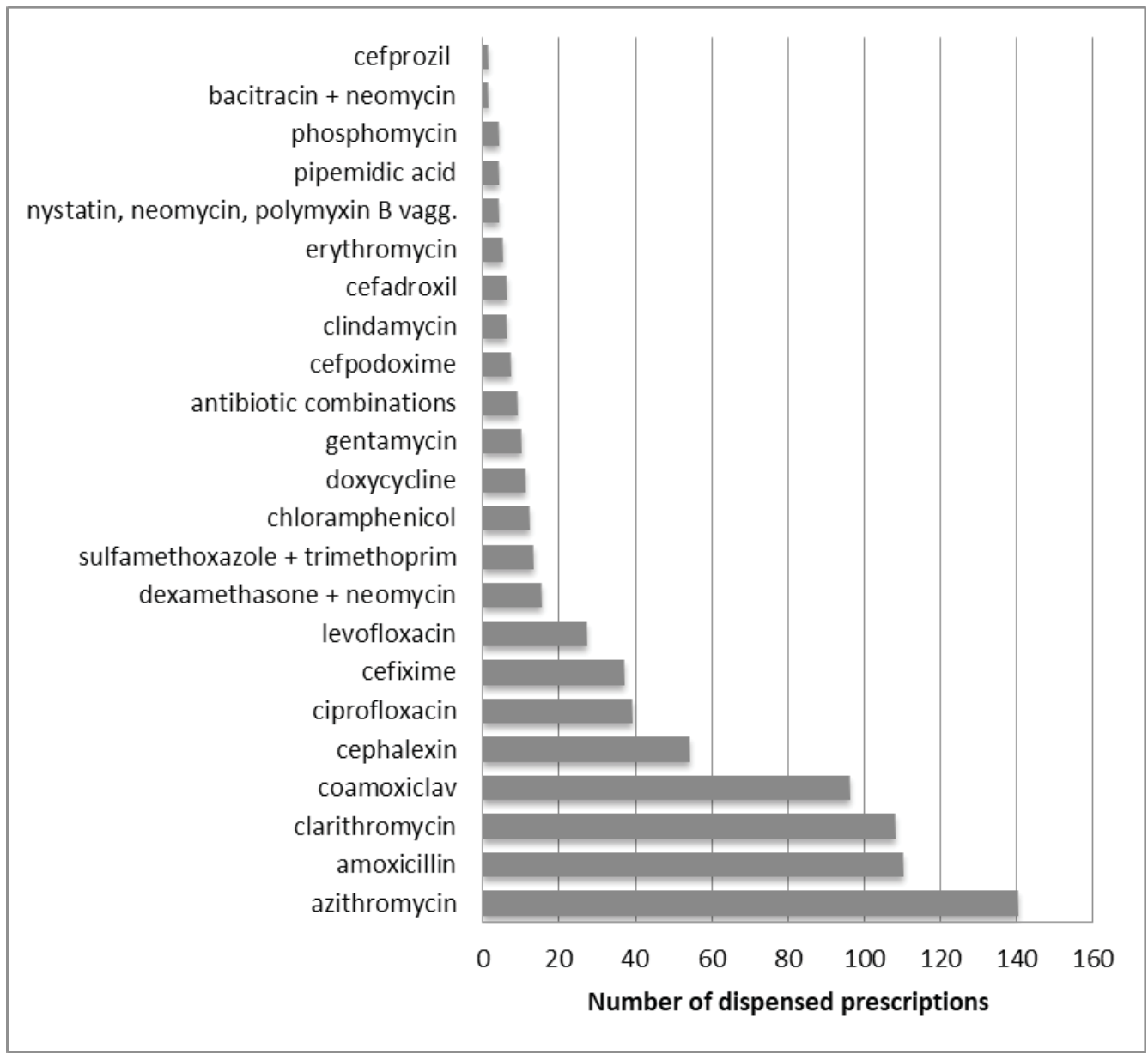


Out of 454 analyzed TTD, 404 (88.98\%) were prescribed and issued for the treatment of acute respiratory. Acute pharyngitis was the most common diagnosis for which antibiotics were prescribed and 190 (41.85\%) patients became ill with this infection. In $40-60 \%$ of cases, it is primarily of viral and $5-30 \%$ of bacterial origin [12]. In line with national guidelines were 140 (73.68\%) of TTD. The second most frequent was bronchitis $51(11.23 \%)$, which was of viral origin in $90 \%$ of cases $[12,22,23]$. Given the primary etiology of the disease, national guidelines suggest administration and prescribing of antibiotics only in the case of comorbidities or in people over 65 years of age. For the first two MCD, macrolide antibiotic was predominantly prescribed. Similar results were obtained in a study conducted in Italy where the MCD was acute pharyngitis $(60.4 \%)$ and the second most frequent was acute bronchitis (18.2\%) [11]. Globally, acute sinusitis in adults is usually of viral etiology. Antibiotics are prescribed if a patient's condition does not improve after 10 days, [12,18-20]. Levofloxacin, azithromycin and broad-spectrum penicillin were the most commonly prescribed antibiotics in our study. Current guidelines do not recommend macrolides or fluoroquinolones as the first-line antibiotics, therefore special attention should be given when diagnosing patients, as well as prescribing and dispensing appropriate therapy [12].

This study examined 719 (5.48\%) antibiotic prescriptions issued by the pharmacy institution out of a total of 13115 NHIF prescriptions issued in January 2018. The most commonly prescribed antibiotic groups were macrolides (35.19\%), penicillins (28.68\%), cephalosporins $(14.6 \%)$ and fluoroquinolones (9.18\%). In 2008 an antibiotic consumption study was performed in the South Backa District (SBD) and the obtained results were compared with antibiotic consumption in Finland and Denmark during the same period. Penicillins were the most commonly prescribed antibiotics in all three countries [24]. The most commonly prescribed antibiotics in Romania in 2008 were broad-spectrum penicillins, second-generation cephalosporins and fluoroquinolones [25]. The results obtained from these studies show changes in the prescribing practices of primary care physicians. Macrolides were the most commonly prescribed antibiotics in our study with a proportion of $35.19 \%$.
In a study conducted in Italy in 2017, the most commonly prescribed were macrolides (32.5\%), broad-spectrum penicillins (31.1\%) and fluoroquinolones (14.2\%) [11]. Italy is a country with a high consumption of antibiotics [26], especially for prophylactic purposes [27] and one of the countries with the fastest growth of antibiotic resistance [28]. Inappropriate use of antibiotics can lead to an increase in antibiotic resistance and, consequently, to an increase in morbidity and/or mortality rate, and costs of treatment, [29 - 31]. For almost every third diagnosis in this study $(28.65 \%)$ there was no recommended therapy included in national guidelines. There are several reasons for the inappropriate use of antibiotics: failure to adhere to national guidelines, lack of knowledge and professional training, pressure from pharmaceutical companies, the financial benefit for physicians, and patient pressure on doctors to prescribe antibiotics even when they are not necessary [32-38]. One of the most important steps to slow down the development and spread of resistance is the rational use of antibiotics [39], per local guidelines, which are based on local antibiotic resistance maps [3]. Due to the implementation of new guidelines, adopted at the end of 2018, shortly after data collection for this study, it is extremely important to assess the adherence of rational use of antibiotics to the previous ones.

\section{CONCLUSION}

This study has shown a significant deviation of prescribing practice in primary care from national guidelines. The highest deviation was recorded in acute bronchitis and the most commonly prescribed antibiotic was azithromycin. For almost every third diagnosis in this study, the prescribed therapy was not included in national guidelines. Irrational prescribing and dispensing of antibiotics is a global problem. It is necessary to pay close attention to antibiotics prescribing and dispensing. The focus should be on adherence to national guidelines and their expansion.

This study has limitations in sense of short observation period, and a need for a larger sample pool from more pharmacies in order to acquire more representative data. Prescriptions for antibiotics with dosage based on body weight were excluded from the study. There was no information about special groups of patients who require particular doses calcu- 
lations (including pregnant women, patients with kidney and liver disease etc). Prescriptions that were not funded by NHIF were not included in the study.

\section{ACKNOWLEDGEMENTS}

This work has been supported by Ministry of Science and Technology Development of Serbia (grants 41012, 172053 and TP31071-2).

\section{CONFLICTS OF INTEREST}

All authors declare no conflict of interest.

\section{REFERENCES}

1. Holstiege J, Garbe E. Systemic antibiotic use among children and adolescents in Germany: a population-based study. European Journal of Pediatrics. 2013;172(6):787-795.

2. Malhotra-Kumar S, Lammens C, Coenen S, Van Herck K, Goossens H. Effect of azithromycin and clarithromycin therapy on pharyngeal carriage of macrolide-resistant streptococci in healthy volunteers: a randomised, double-blind, placebo-controlled study. The Lancet. 2007;369(9560):482-90.

3. Www.who.int [Internet]. Global Action Plan on Antimicrobial Resistance; 2015 [cited 2019 September 14]. Available at: https://apps.who.int/iris/ bitstream/handle/10665/193736/9789241509763_ eng. pdf?sequence $=1$ \&isAllowed $=y$

4. Sundvall PD, Stuart B, Davis M, Roderick P, Moore $M$. Antibiotic use in the care home setting: a retrospective cohort study analysing routine data. BMC geriatrics. 2015;15(1):71.

5. European Centre for Disease Prevention and Control. Antimicrobial resistance surveillance in Europe 2012. Annual report of the European Antimicrobial Resistance Surveillance Network (EARS-Net). Stockholm: ECDC; 2013.

6. Klein E, Van Boeckel T, Martinez E, Pant S, Gandra S, Levin $S$ et al. Global increase and geographic convergence in antibiotic consumption between 2000 and 2015. Proceedings of the National Academy of Sciences. 2018;115(15):E3463-70.

7. Pechère JC, Hughes $D$, Kardas $P$, Cornaglia $G$. Non-compliance with antibiotic therapy for acute community infections: a global survey. International journal of antimicrobial agents. 2007;29(3):24553.

8. Hansen $M$, Carson $P$, Leedahl $D$, Leedahl $N$. Failure of a Best Practice Alert to Reduce Antibiotic Prescribing Rates for Acute Sinusitis Across an Integrated Health System in the Midwest. Journal of Managed Care \& Specialty Pharmacy. 2018;24(2):154-9.
9. O'Neill J. Tackling Drug-resistant Infections Globally: Final Report and Recommendations-The Review on Antimicrobial Resistance Chaired by Jim O'Neill. Wellcome Trust and HM Government, London. 2016.

10. Www.ema.europa.eu [Internet]. Antimicrobial resistance; [cited 2019 September 10]. Available at: https://www.ema.europa.eu/en/human-regulatory/overview/public-health-threats/antimicrobial-resistance\#european-commission-action-plansection

11. Bianco A, Papadopoli R, Mascaro V, Pileggi C, Pavia M. Antibiotic prescriptions to adults with acute respiratory tract infections by Italian general practitioners. Infection and drug resistance. 2018;11:2199-205.

12. Www.dzsvenac.rs [Internet]. Farmakoterapijski protokoli u primarnoj zdravstvenoj zaštiti najčešće bolesti i stanja; 2014 [In Serbian] [cited 2019 September 10]. Available at: http://www. dzsvenac.rs/uputstvo/rfzo/PROTOKOLI\%2020_ jul_2014.pdf

13. Pouwels KB, Dolk FC, Smith DR, Robotham JV, Smieszek T. Actual versus 'ideal' antibiotic prescribing for common conditions in English primary care. Journal of Antimicrobial Chemotherapy. 2018;73(2):19-26.

14. Smith D, Dolk F, Pouwels K, Christie M, Robotham J, Smieszek T. Defining the appropriateness and inappropriateness of antibiotic prescribing in primary care. Journal of Antimicrobial Chemotherapy. 2018;73(2):ii11-8.

15. Kraus E, Pelzl S, Szecsenyi J, Laux G. Antibiotic prescribing for acute lower respiratory tract infections (LRTI) - guideline adherence in the German primary care setting: An analysis of routine data. Рлос оне. 2017;12(3):e0174584.

16. Gasson J, Blockman M, Willems B. Antibiotic prescribing practice and adherence to guidelines in primary care in the Cape Town Metro District, South Africa. South African Medical Journal. 2018;108(4):304-10.

17. Www.who.int [Internet]. Community-based Surveillance of Antimicrobial Use and Resistance; 2009 [cited 2019 September]. Available at: http:// www.who.int/medicines/publications/community based_may09.pdf?ua=1 (accessed 08 September 2019).

18. Rosenfeld RM, Piccirillo JF, Chandrasekhar SS, Brook I, Ashok Kumar K, Kramper M, et al. Clinical practice guideline (update): adult sinusitis. Otolaryngology-Head and Neck Surgery. 2015;152(2):S139.

19. Aring AM, Chan MM. Current Concepts in Adult Acute Rhinosinusitis. American family physician. 2016;94(2):97-105.

20. McCullough A, Pollack A, Plejdrup Hansen $M$, Glasziou P, Looke D, et al. Antibiotics for acute re- 
spiratory infections in general practice: comparison of prescribing rates with guideline recommendations. Medical Journal of Australia. 2017;207(2):659.

21. Harris AM, Hicks LA, Qaseem A. Appropriate antibiotic use for acute respiratory tract infection in adults: advice for high-value care from the American College of Physicians and the Centers for Disease Control and Prevention. Annals of internal medicine. 2016 Mar 15;164(6):425-34.

22. Gonzales R, Anderer T, McCulloch CE, Maselli JH, Bloom FJ, Graf TR, Stahl M, Yefko M, Molecavage J, Metlay JP. A cluster randomized trial of decision support strategies for reducing antibiotic use in acute bronchitis. JAMA internal medicine. 2013;173(4):267-73.

23. Barnett ML, Linder JA. Antibiotic prescribing for adults with acute bronchitis in the United States, 1996-2010. Jama. 2014;311(19):2020-2.

24. Horvat O, Mijatović V, Milijasević B, Tomas A, Kusturica MP, Tomić Z, Sabo A. are There striking Differences in Outpatient Use of antibiotics Between south Backa District, Serbia, and some Scandinavian countries?. Frontiers in public health. 2018;6:91.

25. Ion-Nedelcu N, Radu L, Firulescu S, Truță E, Sîrbu M, Barbu G, Calistru P. Use of systemic antibacterial agents at a university emergency clinic in Bucharest, in the year 2008. Bacteriologia, virusologia, parazitologia, epidemiologia (Bucharest, Romania: 1990). 2009;54(1):53-8.

26. Butler CC, Francis N. Commentary: Controversies in NICE guidance on antibiotic prescribing for self limiting respiratory tract infections in primary care. Bmj. 2008;337:a656.

27. European Centre for Disease Prevention and Control. Summary of the latest data on antibiotic consumption in the European Union ESAC-Net surveillance data; 2017.

28. Giordano M, Squillace L, Pavia M. Appropriateness of surgical antibiotic prophylaxis in pediatric patients in Italy. infection control \& hospital epidemiology. 2017;38(7):823-31.

29. Laxminarayan R, Matsoso P, Pant S, Brower C, Røttingen JA, Klugman K, Davies S. Access to effective antimicrobials: a worldwide challenge. The Lancet. 2016;387(10014):168-75.

30. Loeffler JM, Garbino J, Lew D, Harbarth S, Rohner P. Antibiotic consumption, bacterial resistance and their correlation in a Swiss university hospital and its adult intensive care units. Scandinavian journal of infectious diseases. 2003;35(1112):843-50.

31. Frank U, Kleissle EM, Daschner FD, Leibovici L, Paul M, Andreassen S, Schonheyder HC, Cauda R, Tacconelli E. Multicentre study of antimicrobial resistance and antibiotic consumption among 6,780 patients with bloodstream infections. European
Journal of Clinical Microbiology and Infectious Diseases. 2006;25(12):815.

32. Kotwani A, Wattal C, Katewa S, Joshi PC, Holloway K. Factors influencing primary care physicians to prescribe antibiotics in Delhi India. Family practice. 2010;27(6):684-90.

33. Radyowijati A, Haak H. Improving antibiotic use in low-income countries: an overview of evidence on determinants. Social science \& medicine. 2003;57(4):733-44.

34. Holloway KA, Henry D. WHO essential medicines policies and use in developing and transitional countries: an analysis of reported policy implementation and medicines use surveys. PLoS medicine. 2014;11(9):e1001724.

35. Hassali MA, Kamil TK, Md Yusof FA, Alrasheedy AA, Yusoff ZM, Saleem F, et al. General practitioners' knowledge, attitude and prescribing of antibiotics for upper respiratory tract infections in Selangor, Malaysia: findings and implications. Expert review of anti-infective therapy. 2015;13(4):511. 20.

36. Riaz H, Godman B, Hussain S, Malik F, Mahmood $\mathrm{S}$, Shami A, Bashir S. Prescribing of bisphosphonates and antibiotics in P akistan: challenges and opportunities for the future. Journal of Pharmaceutical Health Services Research. 2015;6(2):111-21.

37. Li Y, Xu J, Wang F, Wang B, Liu L, Hou W, et al. Overprescribing in China, driven by financial incentives, results in very high use of antibiotics, injections, and corticosteroids. Health affairs. 2012;31(5):1075-82.

38. Park S, Soumerai SB, Adams AS, Finkelstein JA, Jang S, Ross-Degnan D. Antibiotic use following a Korean national policy to prohibit medication dispensing by physicians. Health policy and planning. 2005;20(5):302-9.

39. Earnshaw S, Mendez A, Monnet DL, Hicks L, Cruickshank M, Weekes L, Njoo H, Ross S. Global collaboration to encourage prudent antibiotic use. The Lancet infectious diseases. 2013;13(12):10034. 


\title{
Propisivačka praksa antibiotika u primarnoj zdravstvenoj zaštiti iz ugla farmaceuta
}

\author{
Bojana Z. Čović ${ }^{1,2}$, Nemanja B. Todorović́ ${ }^{2}$ Jelena M. Čanji ${ }^{2}$, Katarina D. Jeremić ${ }^{2}$, \\ Jelena N. Jovičić-Bata ${ }^{2}$, Đurđa M. Cvjetkovićs ${ }^{3}$ Mladena N. Lalić-Popović2,4 \\ ${ }^{1}$ Alkaloid AD Skopje, Beograd, Srbija \\ ${ }^{2}$ Katedra za farmaciju, Medicinski fakultet Novi Sad, Univerzitet u Novom Sadu, Novi Sad, Srbija \\ ${ }^{3}$ Katedra za farmakologiju, toksikologiju i kliničku farmakologiju, Medicinski fakultet Novi Sad, \\ Univerzitet u Novom Sadu, Novi Sad, Srbija \\ ${ }^{4}$ Centar za medicinsko-farmaceutska istraživanja i kontrolu kvaliteta (CEMFIK), Medicinski fakultet Novi \\ Sad, Univerzitet u Novom Sadu, Novi Sad, Srbija
}

\section{KRATAK SADRŽAJ}

Uvod: Antimikrobna rezistencija je globalni problem. Pridržavanje lokalnim smernicama prilikom propisivanja antibiotika je ključni faktor za njihovu racionalnu upotrebu. Cilj: Cilj studije je bio da se odrede karakteristike propisivačke prakse antibiotika u primarnoj zdravstvenoj zaštiti u Novom Sadu (Srbija).

Metoda: Ispitivanje je dizajnirano kao opservaciona, deskriptivna, retrospektivna studija zasnovana na podacima dobijenim iz zdravstvene ustanove apoteke Cvejić. Za procenu usklađenosti propisanih antibiotika sa smernicama, korišćene su smernice koje su bile dostupne lekarima u trenutku propisivanja kao najnovije. Posmatrana je potrošnja izražena kao procenat za svaki pojedinačni farmaceutski sastojak.

Rezultati: Studija je pokazala da su antibiotski recepti činili 5,48\% svih recepata (719 od 13115$)$, od toga $513(71,35 \%)$ recepata je propisano za najčešće dijagnoze, a $206(28,65 \%)$ za manje učestale dijagnoze čije smernice nisu propisane nacionalnim vodičima. U ispitivanom uzorku 297 (65,42\%) je imalo dobro propisanu dozu. Najčešće propisivane antibiotske grupe su bile: makrolidi $(35,18 \%)$, penicilini $(28,68 \%)$ i cefalosporini $(14,60 \%)$.

Zaključak: Neracionalno propisivanje i izdravanje antibiotskih lekova je problem kako na nacionalnom nivou tako i na globalnom nivou. Potrebno je usmeriti dodatnu pažnju prilikom propisivanja i izadavnja lekova. Praćenje nacionalnih smernica je od ključne važnosti, kao i razmatranje o proširivanju isitih.

Ključne reči: propisivačka praksa, smernice, propisivanje i izdavanje antibiotika, bakterijska rezistencija 